\title{
Investigating the Relationship between Customer Knowledge Management and Knowledge Sharing among Insurance Companies in Malaysia
}

\author{
Ahmad Suffian Mohd Zahari ${ }^{1}$, Baharom Ab Rahman ${ }^{1}$, Abdul Kadir Othman ${ }^{2} \&$ Samsudin Wahab ${ }^{2}$ \\ ${ }^{1}$ Centre for Applied Management, Faculty of Business Management, Universiti Teknologi MARA Terengganu, \\ Dungun, Malaysia \\ ${ }^{2}$ Centre for Applied Management, Faculty of Office Management and Technology, Universiti Teknologi MARA \\ Kampus Puncak Alam, Bandar Puncak Alam, Malaysia \\ Correspondence: Abdul Kadir Othman, Centre for Applied Management, Faculty of Office Management and \\ Technology, Universiti Teknologi MARA Kampus Puncak Alam, 42300 Bandar Puncak Alam, Selangor, \\ Malaysia. Tel: 60-13-982-3953. E-mail: abdkadir@salam.uitm.edu.my
}

Received: April 16, 2013 Accepted: June 4, 2013 Online Published: August 1, 2013

doi:10.5539/ass.v9n10p60 URL: http://dx.doi.org/10.5539/ass.v9n10p60

\begin{abstract}
Recently, customer knowledge management has been widely recognized as a determinant of business performance. However, knowledge of customers that the organization gathers is useless unless it is shared internally. Sharing of this knowledge among organizational members will greatly strengthen the competitiveness of the organization, which makes it possible to take advantage of the competitive dynamics in the business environment. Although the importance of knowledge sharing especially the one that is related to customers has long been recognized by the community of researchers, investigation in this area is very limited. Therefore, the present study was conducted to investigate the relationship between Customer Knowledge Management dimensions, which consist of knowledge for customers, knowledge about customers, knowledge from the customer and knowledge sharing among insurance companies in Malaysia. A total of 180 managers of insurance companies in Malaysia participated in the survey. The results show that the three knowledge dimensions are positively and significantly related to knowledge sharing. Moreover, the results indicate that the insurance companies have implemented knowledge sharing practices especially in securing and managing their customer data to ensure the currency, accuracy, uniqueness and completeness of the customer data. Finally, research and practical implications are discussed.
\end{abstract}

Keywords: customer knowledge management (CKM), knowledge, knowledge sharing (KS), performance

\section{Introduction}

Knowledge has been widely recognized as a determinant of organizational performance. Business capability and effectiveness require an effective sharing of resources and knowledge. In particular, Knowledge sharing among different companies and departments can improve organizational processes since intangible knowledge plays an important role in achieving competitive advantage. According to Abdul Kadir (2010), business main objective for existence is to gain competitive advantage in the marketplace. Nowadays, the elements of competitiveness in the organization have gradually shifted from labor and capital emphases to its unique and sustainable resource, which is knowledge. The 21 st century will be the century of knowledge, where the ability to control and manage knowledge effectively plays an important role in maintaining the company's competitive advantage and survival. Therefore, Customer Knowledge Management (CKM) is regarded as a competitive asset in creating value for the organization.

In CKM setting, knowledge sharing between organizations internally and externally will greatly enhance the core competitiveness of the organization, which makes it possible to bring dynamic competitive advantages into full play in market development and technology. In other words, research on CKM and knowledge sharing within organizations is very important. Currently, knowledge has become the most powerful asset in the world. Therefore, it is mandatory to take advantage of the knowledge that resides in the organization. Knowledge is power, so what people know and what they know is a valuable asset to them personally and to the company. 
Therefore, knowledge sharing is needed to give businesses a competitive edge they need to survive in a challenging economy. Knowledge must be shared among employees to support corporate vision and mission. Thus, knowledge is considered as a key driver of any successful business today.

It is inevitable that knowledge sharing among employees in organization provides clear benefits for the people and better business performance for the organization. Many organizations begin to realize that keeping data and information without sharing them is not enough to maintain a competitive edge in the business world. As a result, knowledge of the organization's assets must be shared and managed by the organization in order to become competitive. Therefore, the purpose of this paper is to investigate the relationship between CKM and knowledge sharing.

\section{Literature Review}

\subsection{Knowledge Based View}

Knowledge-based view (KBV) of the firm is derived from the resource-based view (RBV) of the firm. It claims that knowledge is the main source of productive firm (Grant, 1996; Spender \& Grant, 1996; Von Krogh \& Roos, 1996; Liebeskind, 1996). The KBV of the firm focuses on knowledge as the most important strategic firm's resource. It is not surprising that knowledge sharing has gained wide attention from the past strategic management literature. A concept of knowledge sharing, particularly addressed in the strategic management literature, is the realization of competitive advantage through effective sharing of knowledge.

Organizational knowledge sharing is a key component of this view because researchers have found that sharing knowledge is the key to organizational productivity (Almeida \& Kogut, 1999; Hansen, 2002; Kostova, 1999). According to Davenport and Prusak (1998), unlike material assets that depreciate in value with use, knowledge assets appreciate in value with the use of new ideas and shared knowledge stays with the giver while enriching the receiver. Hence, with an effective sharing process an organization can develop its knowledge base and enhance its competitiveness (Andrews \& Deiahaye, 2000; McEvily \& Chakravarthy, 2002).

People are important to knowledge sharing and the sustenance of a competitive advantage is grounded in the $\mathrm{KBV}$ of the firm. When the managers of the organizations manage the knowledge of their company internally, they create tangible goods and intangible structure as a better process and a new design for the product (Grant, 1991). When they managed to exploit the knowledge, in delivering goods and services, they also create intangible structure, such as explicit knowledge, customer relationship, reputation and new experience for the customers (Grant, 1991). This process of knowledge sharing, both within and outside the organization becomes a critical factor for the organizational performance and this is exactly the way sharing knowledge is conceptualized for the purpose of this paper.

\subsection{Customer Knowledge Management (CKM)}

Customer Knowledge Management (CKM) refers to the management of customer knowledge (Rowley, 2002). By understanding the customers' needs and wants, it is important for businesses to streamline processes, products and services in order to build sustainable customer relationships. However, this understanding must be shared among departments because organization consists of interdependent units, working together to serve the customers. Sharing the customer knowledge as one type of knowledge sharing can help firms to identify present and latent customer needs. Until now, most companies have focused on collecting vast amounts of data about their customers, but they do not know how to deal with them (Davenport, 2001).

The concept of CKM has been firstly advocated by Gibbert, Leibold, and Probst (2002), who describe CKM as the strategic process by which cutting edge companies emancipate their customers from passive recipient of products and services, to empowerment as knowledge partners. They said that CKM is about getting, sharing, and expanding customer knowledge that resides in, to both customer and corporate benefits. It can take the form of prosumerism, joint innovation, with team-based learning, communities of practice, and joint intellectual property (IP) management. In their paper, CKM reflects customer knowledge management, the knowledge that resides in the client, in contrast to the knowledge of the customer, which is the classical knowledge used in Customer Relationship Management (CRM) system. The second is Gebert, Gelb, Kolbe, and Brenner (2002) from University of St. Gallen, who develop their CKM concept through reflections on CRM and the use of knowledge gathered to support business processes. The task of CKM, as highlighted by them, is to design the knowledge flow inside and between the CRM processes and to allocate relevant knowledge gained from customer-related processes to others. Three main dimensions of CK are classified in their studies known as knowledge for customers, knowledge about customers, and knowledge from customers.

Knowledge about customers refers to customer segments and individual customers. It can be captured through 
customer surveys, service management and customer complaints. It is accumulated to understand motivations and to address customers in a personalized way. Knowledge about customers also includes demographic data, customer history, contacts, needs, expectations and buying patterns. It is necessary to manage data on a continuous basis; otherwise, they quickly become worthless. Knowledge about customers should lead to improvements in the effectiveness and efficiency of the internal business processes, for examples, the productivity of customer service representative; the reduction in learning curve, and the acceleration of product and service projection.

Knowledge for customers is generated in the process within the enterprise, such as research and development. It is required in the CRM process to meet the needs of customer. In other words, this knowledge is produced from organizations to customers and suppliers. For example, the organization will provide knowledge about product and knowledge about market and suppliers to customers so that the customers become aware of the current trend in the market.

Knowledge from customers is the knowledge captured from the customer database. Customers get their own expertise while using the product or service at the same time improving the customer experience with the firm. During the interaction with the customer, this knowledge can be gathered to feed continuous improvement, such as improvements or new product development. No matter what the client knowledge is collected, it is important to manage and organize it properly. As a result, organization can develop partnerships with customers to produce innovative products and services that can improve organizational performance.

The three types of knowledge flows deliver significant short-term as well as long term benefits for the organization. Furthermore, the knowledge gained from communication with the customers will usually lead to an increase in overall organizational services and products. It also helps the organization to better serve the needs of clients and enables them to better understand the needs of customers. In addition, being in touch with clients may help in addressing some of the customers' concern. However, all three streams of customer knowledge must be shared within the organization to achieve organizational effectiveness.

\subsection{Customer Knowledge Management and Knowledge Sharing (KS)}

By definition, CKM is about gaining, sharing, and expanding the knowledge that resides in customers for the benefit of both customers and organization (Gibbert et al., 2002). Yang and $\mathrm{Wu}$ (2008) define knowledge sharing as an activity in which knowledge of a person, a group or an organization is transferred or spread to other people, another group or organization. Knowledge sharing enables managers to ensure individual learning throughout the company and to integrate the practical applications of the outcome. In addition, the people in an organization, by way of sharing thoughts, beliefs, knowledge and experience, can create mutual understanding. This approach not only increases the capacity of workers, but also contributes to overall organizational effectiveness and profitability.

Knowledge sharing refers to a process organized through various modes of communication that pass on the knowledge to the members in the best time, place and form (Zhang, Liu \& Xiao, 2008). In addition, the sharing process consists of collecting, organizing and conversing knowledge from one to another (Van den Hooff \& De Ridder, 2004). Thus, if knowledge is properly managed, knowledge sharing can greatly improve the quality of work and decision making skills, problem-solving competencies that will benefit the organization at large (Syed Omar \& Rowland, 2004; Yang, 2007).

Knowledge sharing also refers to a process of interpersonal interaction in which the exchange of knowledge occurs (Fatt \& Khin, 2010; Makela \& Brewster, 2009; Okyere-Kwakye \& Nor, 2011). Previous studies were conducted to understand the dimensions of knowledge sharing. For examples, trust among individuals (Wang, Liang \& Chen, 2010), leadership styles (Liu \& Phillips, 2011) and network connectivity (Makela \& Brewster, 2009). On the other hand, several studies have shown that knowledge sharing is important for a variety of organizational phenomena, such as service innovation (Cavusgil, Calantone \& Zhao, 2003), employee satisfaction (Ku \& Fan, 2009) and new product development (Hansen, 1999).

In a dynamic business environment, employees must have sufficient knowledge of target customers in order to satisfy them (Desarbo, Jedidi \& Sinha, 2001). Knowing the needs of customers, firms can deliver superior customer value (Zhou, Brown \& Dev, 2009). It is argued that firms need to encourage knowledge sharing among employees (McLean, 2005) because relevant feedback from knowledgeable colleagues is crucial in understanding customers' demand and expectations. This sharing of knowledge improves employees' innovativeness and performance. Thus, firms should encourage employees to share their knowledge regarding the selling practices, strengths and weaknesses of their firm's competitors (Tsiotsou, 2010; Zhou, Brown \& Dev, 2009). Sharing of this knowledge can help employees to develop products and services that are competitive 
(Sorensen, 2009) and responsive to customers' needs (Jaworski \& Kohli, 1990).

\subsection{Knowledge for Customer and Performance}

Knowledge for customers is transmitted from one direction to support the organization, customers and to make customers better understand the products the organization offers (Gebert et al., 2002; Smith \& McKeen, 2005). This knowledge flow produces greater value when it exists (Ma \& Qi, 2009). It helps organizations to retain current customers and subsequently improve the organization profits. Knowledge sharing is an important step in customer knowledge management (Ma \& Qi, 2009). Organization must develop an effective knowledge sharing process and encourage its employees and partners to share knowledge about customers, competitors, markets, and products (Bock \& Kim, 2002). The sharing should also involve the higher level officials in the organizations because they could use this knowledge to make product related decisions (Garcia \& Annabi, 2002). Based on the discussion, the following hypothesis is developed:

H1: Knowledge for customers positively influences knowledge sharing.

\subsection{Knowledge about Customers and Performance}

Knowledge about customers is a firm's understanding on the background of clients, needs and preferences for product features (Chen \& Su, 2006). Customers interact with organizations through a variety of different channels such as email and Facebook. When the knowledge about customers has been captured based on the types of channels they interact, organization can share and segment their customers according to their unique profiles and also determine the types of relationship with them. Therefore, the use and share of customer database are very important to keep and update all knowledge about customers. According to Ma and Qi (2009), the process of sharing knowledge about customers is the process of learning. The purpose of customer knowledge sharing is to promote the knowledge flow in organizations among its member to make them more knowledgeable. Based on the above discussion, the following hypothesis is suggested:

$\mathrm{H} 2$ : Knowledge about customers positively influences knowledge sharing.

\subsection{Knowledge from Customers and Performance}

Knowledge from customers consists of customer's knowledge about products and services, organizations, customers, competitors' input for product development and innovation, and their choice of communication channels (Feng \& Tian, 2005). Knowledge from customers can be generated from the data obtained through direct customer complaints, needs and suggestions. Therefore, the knowledge sharing within organizations can help organizations to focus on the right market segments and to adopt the appropriate business strategy for product development and marketing activities (Chen \& Su, 2006; Park \& Kim, 2003). Tay and Shanks (2001) acknowledge that the organization can increase the use of customer knowledge to gain competitive advantage. Moreover, the sharing of knowledge has been developed more recently as a way of fostering collaboration and idea generation in organizations (Garcia \& Annabi, 2002). Based on the above discussion, the following hypothesis is suggested:

H3: Knowledge from customers positively influences knowledge sharing.

Based on the discussion, the following research framework is proposed to illustrate the relationship between the independent variables that consist of knowledge for customers, knowledge about customers and knowledge from customers; and knowledge sharing.

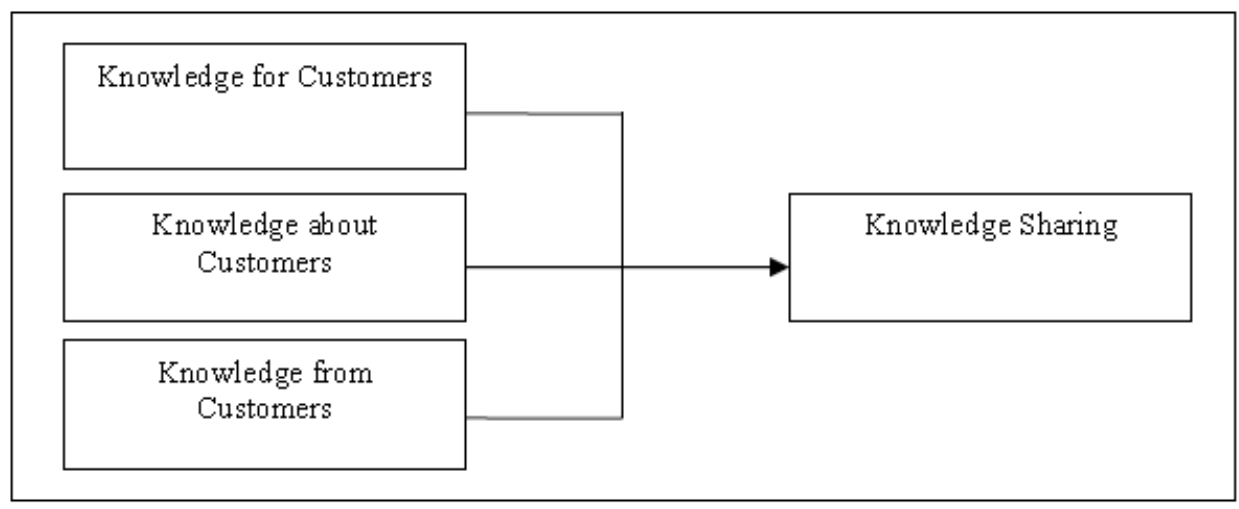

Figure 1. The hypothesized relationship between the CKM dimensions and knowledge sharing 


\section{Methodology}

\subsection{Research Design}

The study was conducted specifically to investigate the influence of CKM dimensions on knowledge sharing. The CKM dimensions that consist of knowledge for customers, knowledge about customers and knowledge from customers have been identified as the independent variables while knowledge sharing is the dependent variable. To achieve the objective of the study, a correlational research design was used to investigate the relationship between the two types of variables.

\subsection{Instruments}

Initially, a sixty item measurement of Customer Knowledge Management was adapted from Belkahla and Triki (2011). However, after the review and revision of the original measurement by the experts among the academics and industrial practitioners, thirty nine items have been adapted and modified to suit the CKM dimensions that comprise Knowledge for Customers, Knowledge about Customers and Knowledge from Customers. Respondents were required to answer each item using five-point Likert scale, ranging from $5=$ strongly agree to $1=$ strongly disagree. Then, the adapted and modified questionnaire was again reviewed by four academicians who were the experts in the field of CKM and business and by managers who had years of experience in the sector of insurance and service industries. The feedbacks from the reviewers were collected and some modifications were subsequently made on the questionnaire. Knowledge sharing measurement was adapted from Kang, Kim, and Chang (2008). This factor was measured using four items utilizing a five-point Likert scale, ranging from $5=$ strongly agree to $1=$ strongly disagree.

\subsubsection{Sampling}

A comprehensive list of insurance companies in Malaysia serves as the sampling frame in the study. The sampling frame was obtained from the database of Bank Negara Malaysia. The company size in the sampling frame, measured in number of employees, ranged from 25 to more than 100. The age of companies spanned from 5 to more than 20 years. The annual revenues of the companies varied from 10 million to more than 50 million.

A stratified random sampling was used to select approximately equal number of managers from each type of insurance companies. The reasons for using stratified random sampling are; first, there are different categories of insurance companies; second, each category has elements with similar characteristics within the group and different characteristics among the groups; and third, by using stratified, the representativeness of the sample can be assured.

Managers, marketing managers or assistant managers who were knowledgeable about the CKM implementation in their companies were selected as key informants. Typically, these respondents are senior managers in their respective organizations.

During the data collection process, a total of 500 sets of questionnaires were distributed to the managers of insurance companies in Peninsular Malaysia, Sabah and Sarawak. These insurance companies were listed in the Bank Negara Malaysia databases. However, after the follow up and the lapse of data collection period, a total of 180 managers responded to the given questionnaire, indicating a response rate of $37 \%$.

\section{Data Analysis and Findings}

4.1 Profile of Respondents

Table 1. The profiles of respondents $(\mathrm{N}=180)$

\begin{tabular}{lcc}
\hline CKM Implementation & Frequency & \% \\
Formal & & \\
Informal & 124 & 70.5 \\
No & 33 & 18.8 \\
Job Position & 19 & 10.8 \\
Regional Manager & & \\
Branch Manager & 21 & 11.7 \\
Assistant Manager & 86 & 47.8 \\
Branch Executive & 11 & 6.1 \\
Others & 45 & 25 \\
& 9 & 5.0
\end{tabular}




\section{Length of Service}

$1-5$ years 63

35.0

$6-10$ years

$11-15$ years 16.1

$16-20$ years 12.8

More than 21 years

\section{Department}

Human Resource

Knowledge Management \& IT

Marketing

Others

\section{Category of insurance}

Life

General

Life Takaful

General Takaful

Others

Number of Employees

Less than 25

$26-75$

$76-100$

More than 100

\section{Company Operating (years)}

Less than 5 years

6 years -10 years

Organization's Annual Revenue

Less than RM20 million

Table 1 shows that the majority of insurance companies implement formal customer knowledge management which is $70.5 \%, 18.8 \%$ implement informal customer knowledge management and $10.8 \%$ does not have customer knowledge management. The positions held by the respondents are Regional Manager (11.7\%), Branch Manager (47.8\%), Assistant Manager (6.1\%), Branch Executive (25\%), and Others (5\%).

Most of the respondents (35.0\%) have been working between 1 to 5 years, $22.2 \%$ of the respondents have been working between 6 to 10 years, $16.1 \%$ of the respondents have 11 to 15 years working experience, $12.8 \%$ of the respondents have 16 to 20 years of working experience in the business and $4.42 \%$ of the respondents have been working for 21 to 25 years and more than 26 years.

Table 1 also shows that $17.4 \%$ of the respondents are attached with the Human Resource Department, $16.3 \%$ with Knowledge Management and Information Technology, 43.3\% with Marketing, and 23\% with other departments. General insurance contributes $51.1 \%$ to the total category of respondents. It is followed by Life insurance (24.4\%), Life Takaful (18.3\%) and General Takaful (5\%). From the number of employees it can be observed that the majority of companies $(48.6 \%$ ) have less than 25 employees, followed by $32.4 \%$ of the companies have more than 100 employees, $11.8 \%$ of the companies have 26 to 75 employees, and $7.3 \%$ of the companies have 76 to 100 employees.

Most companies (62.9\%) have been operating their business for more than 20 years, $15.7 \%$ of the companies have been in operation for 6 to 10 years, $9 \%$ of the companies have less than 5 years of business operation and $6.2 \%$ of the companies have been operating for 11 to 15 years. Regarding the annual revenue, majority of the companies (69.8\%) generate more than RM50 million, $11.8 \%$ of the companies earn less than RM20 million, and $18.5 \%$ of the companies secure between RM21 to RM40 million annual revenue. 


\subsection{Reliability, Means, Standard Deviation and the Correlation Analysis Result}

Table 2. Reliability, means, standard deviation and the correlation analysis result

\begin{tabular}{llcccccc}
\hline No & \multicolumn{1}{c}{ Variable } & Mean $(\mathbf{N}=\mathbf{1 8 0})$ & SD & $\mathbf{1}$ & $\mathbf{2}$ & $\mathbf{3}$ & $\mathbf{4}$ \\
\hline 1 & Knowledge for customers & 4.01 & 0.55 & $\mathbf{( 0 . 8 0 )}$ & & & \\
2 & Knowledge about customers & 4.03 & 0.58 & $.614^{* *}$ & $\mathbf{( 0 . 8 1 )}$ & & \\
3 & Knowledge from customers & 3.81 & 0.59 & $.580^{* *}$ & $.567^{* *}$ & $\mathbf{( 0 . 8 9 )}$ & \\
4 & Knowledge Sharing & 4.01 & 0.54 & $.515^{* *}$ & $.495^{* *}$ & $.514^{* *}$ & $\mathbf{( 0 . 8 2 )}$ \\
\hline
\end{tabular}

Notes: ** Correlation is significant at the 0.01 level (2-tailed); * Correlation is significant at the 0.05 level (2-tailed); Cronbach's alphas in the parentheses along the diagonal

Table 2 shows the relationships among CKM dimensions that consist of three customer knowledge constructs and the relationships between CKM dimensions and knowledge sharing. Each construct has acceptable Cronbach's alpha coefficient value which is above 0.60 (Nunnally, 1970). Specifically, the values indicate that the CKM dimensions and knowledge sharing have high internal consistency (knowledge for customer $(0.80)$, knowledge about customer (0.81), knowledge from customer (0.89) and knowledge sharing (0.82)). Previous study by Nejatian et al. (2011) also found that CKM dimensions have very high internal consistency (Knowledge for Customers $=0.95$, Knowledge about Customers $=0.97$ and Knowledge from Customers $=0.96$ ) and 0.88 for knowledge sharing (Kang, Kim \& Chang, 2008). Thus, the internal consistency reliability of these measures can be considered as good.

Correlation was used to describe the strength and direction of the linear relationship between two variables (Pallant, 2011). The relationship among knowledge for customers, knowledge about customers, knowledge from customers, and knowledge sharing were investigated using Pearson correlation coefficient. Table 2 indicates that the correlation values of the variables are between 0.495 and 0.515 . The relationships among knowledge for customers, knowledge about customers, knowledge from customers and knowledge sharing show that there are strong, positive correlations among the variables.

\subsection{Regression Analysis}

Multiple regression analysis is used to test the formulated hypothesis. As can be observed from table 3, the relationship between the independent variables and the dependent variables is significant $(F=32.59, p<.01)$. In this research, the value of $R^{2}$ is .36 , which means that $36 \%$ of the variance in knowledge sharing is significantly explained by the three independent variables. The three dimensions of customer knowledge management were found to contribute positively and significantly in explaining the variance in knowledge sharing, which are knowledge for customers $(\beta=.24, p<0.01)$, knowledge about customers $(\beta=.20, p<0.05)$, and knowledge from customers $(\beta=.26, p<0.01)$. Therefore, Hypotheses 1,2 and 3 are supported.

These results are consistent with those from previous studies by Rollins and Halinen (2005) showing that the organizations should implement inter-functional cooperation wherein customer knowledge is generated and disseminated within the formal and informal meeting and discussions among employees from different departments. The findings obtained in the current study further validate the earlier studies on knowledge sharing such as Bock and Kim (2002) who asserted that an organization must develop an effective knowledge sharing process and encourage its employees and partners to share knowledge about customers, competitors, markets, products and so forth. The findings are also consistent with Platts and Yeung (2000) and Cho, Li and Su (2007) who found that managers most capable of managing others prefer to share their knowledge with others. Riege (2005) suggested that three important elements of knowledge sharing are individual, structure and technology would help organization in encouraging knowledge sharing in the organization. Administrative or managerial control alone does not guarantee successful knowledge sharing (Brown \& Duguid, 1991). 
Table 3. The relationship between knowledge for customers, knowledge about customers, knowledge from customers, and knowledge sharing

\begin{tabular}{lc}
\hline \multicolumn{1}{c}{ Independent Variables } & $\begin{array}{c}\text { Knowledge Sharing } \\
\text { Beta Coefficient }\end{array}$ \\
\hline Knowledge for customers & $.24^{* *}$ \\
Knowledge about customers & $.20^{*}$ \\
Knowledge from customers & $.26^{* *}$ \\
$\mathrm{R}$ & .60 \\
$\mathrm{R}^{2}$ & .36 \\
Adjusted $\mathrm{R}^{2}$ & .35 \\
F value & 32.59 \\
Sig. F value & .000 \\
\hline
\end{tabular}

Note: significant levels: $* * \mathrm{p}<0.01, * \mathrm{p}<0.05$

\section{Conclusion}

\subsection{Managerial Implication}

In recent years where the market competition is very stiff, most organizations agree that the sharing of knowledge among employees and clients can provide better CKM performance, thus can bring economic benefits to companies. Therefore, managers need to develop a successful knowledge-sharing strategy, so that customer knowledge can be a valuable resource for the company. In addition, it is important for managers to conceive and implement a culture of knowledge sharing so that employees can understand the importance of knowledge sharing in the organization and take necessary actions to ensure its effective implementation. Since the culture of the organization serves as a critical factor to the organization's ability to create value through leveraging knowledge assets, it is strictly recommended that organizations should put special emphasis on the sharing of knowledge for the successful implementation of CKM.

CKM implementation in an organization is not an easy task. However, the benefits of knowledge sharing can have a real impact on organizational performance. By actively involving employees and customers in creating a two-way flow of knowledge, an organization can have a new source of knowledge that can enhance the reputation of the business. Finding the right mix of knowledge sharing and right CKM can create a competitive advantage through the introduction of new products and services that can meet the needs of customers. Understanding the importance of customer knowledge organization will promote the development of CKM practice beyond organizational boundaries. This creates a better ability to identify, select, organize, disseminate, and use customer knowledge and of course CKM is a prerequisite for an organization to succeed.

\subsection{Suggestion for Future Research}

The main goal of CKM is to acquire, share and transfer individual knowledge and experience and to convert them into organization's ability. The more individual intellectual capital is converted into the assets of the organization, the stronger the organization becomes. This study shows that the implementation of CKM will contribute to the enhancement of knowledge sharing in the organization and certainly this practice will positively affect organizational performance. For future research, the researchers should look into the strategies that can be used to enhance knowledge sharing practices that are related to Customer Knowledge Management (CKM). By focusing on the right strategies of knowledge sharing, organizations are expected to reap the fullest potential of the CKM implementation.

\section{References}

Almeida, P., \& Kogut, B. (1999). Localization of knowledge and the mobility of engineers in regional networks. Management Science, 45(7), 905-917. http://dx.doi.org/10.1287/mnsc.45.7.905.

Andrews, K. M., \& Delahaye, B. L. (2000). Influences on knowledge processes in organizational learning: The psychosocial filter. Journal of Management Studies, 37(6), 797-810. http://dx.doi.org/10.1111/1467-6486.00204.

Belkahla, W., \& Triki, A. (2011). Customer knowledge enabled innovation capability: Proposing a measurement 
scale. Journal of Knowledge Management, 15(4), 648-674. http://dx.doi.org/0.1108/13673271111152009.

Bock, G. W., \& Kim, Y. G. (2002). Breaking the myths of rewards: An exploratory study of attitudes about knowledge sharing. Information Resources Management Journal, 15(2), 14-21. http://dx.doi.org/10.4018/irmj.2002040102.

Bornemann, M., \& Sammer, M. (2003). Assessment methodology to prioritize knowledge management related activities to support organizational excellence. Measuring Business Excellence, 7(2), 21-28. http://dx.doi.org/10.1108/13683040310477968

Brown, J. S., \& Duguid, P. (1991). Organizational learning and communities-of-practice: Toward a unified view of working, learning, and innovation. Organization Science, 2(1), 40-57. http://dx.doi.org/10.1287/orsc.2.1.40

Cavusgil, S. T., Calantone, R. J., \& Zhao, Y. (2003). Tacit knowledge transfer and firm innovation capability. Journal of Business Industrial Market, 18(1), 6-21. http://dx.doi.org/10.1108/08858620310458615

Chen, Y. H., \& Su, C. T. (2006). A Kano-CKM model for customer knowledge discovery. Total Quality Management \& Business Excellence, 17(5), 589-608. http://dx.doi.org/10.1080/14783360600588158

Cho, N., Li, G. Z., \& Su, C. J. (2007). Empirical study on the effect of individual factors in knowledge sharing by knowledge type. Journal of Global Business and Technology, 3(2), 1-16. Retrieved from http://news-business.vlex.com/vid/empirical-individual-factors-sharing-type-64232151

Davenport, T. H., \& Prusak, L. (1998). Working knowledge: How organizations manage what they know. Cambridge, MA: Harvard Business School Press.

Davenport, T., Harris, J., \& Kohil, A. (2001). How do they know their customers so well? MIT Publisher: Sloan Management Review, 42(2), 63-74. Retrieved from http://sloanreview.mit.edu/article/how-do-they-know-their-customers-so-well/

Desarbo, W. S., Jedidi, K., \& Sinha, I. (2001). Customer value analysis in a heterogeneous market. Journal of Strategy Management, 22(9), 845-857. http://dx.doi.org/10.1002/smj.191

Fatt, C. K., \& Khin, E. W. S. (2010). The social-technical view of knowledge management in services industries. Journal of Social Science, 6(2), 256-264. http://dx.doi.org/10.3844/jssp.2010.256.264

Feng, T. X., \& Tian, J. X. (2005). CKM and condition analysis of successful CKM implementation. In the Fourth International Conference on Machine Learning and Cybernetics, 18-21 August 2005, Guangzhou. http://dx.doi.org/10.1109/ICMLC.2005.1527317.

Garcia-Murillo, M., \& Annabi, H. (2002). Customer knowledge management. Journal of the Operational Research Society, 53(8), 875-884. http://dx.doi.org/10.1057/palgrave.jors.2601365

Gebert, H., Gelb, M., Kolbe, L., \& Brenner, W. (2002). Knowledge-enabled customer relationship management: integrating customer relationship management and knowledge management concepts. Journal of Knowledge Management, 7(5), 107-123. http://dx.doi.org/10.1108/13673270310505421

Gibbert, M., Leibold, M., \& Probst, G. (2002). Five styles of customer knowledge management, and how smart companies use them to create value. European Management Journal, 20(5), 459-469. http://dx.doi.org/10.1016/S0263-2373(02)00101-9

Goh, S. G. (2002). Managing effective knowledge transfer: An integrative framework and some practice $\begin{array}{llll}\text { implications. Journal of Knowledge } & \text { Management, }\end{array}$ http://dx.doi.org/10.1108/13673270210417664

Grant, R. M. (1991). The resource-based theory of competitive advantage - Implications for strategy formulation. California Management Review, 33(3), 114-135. Retrieved from http://www.skynet.ie/ karen/Articles/Grant1_NB.pdf

Grant, R. M. (1996). Toward a knowledge-based theory of the firm. Strategic Management Journal, 17(2), 109-122. http://dx.doi.org/10.2307/2486994

Hansen, M. T. (1999). The search-transfer problem: The role of weak ties in sharing knowledge across organization subunits. Administrative Science Quarterly, 44(3), 82-111. http://dx.doi.org/10.2307/2667032.

Hansen, T. M. (2002). Knowledge networks: Explaining effective knowledge sharing in multi unit companies. Organization Science, 13(3), 232-248. http://dx.doi.org/10.2307/3086019

Jaworski, B. J., \& Kohli, A. K. (1990). Market orientation: The construct, research propositions, and managerial 
implications. Journal of Marketing, 54(5), 1-18. http://dx.doi.org/10.1177/1548051809334189

Kang, Y., Kim, S., \& Chang, G. (2008). The impact of knowledge sharing on work performance: An empirical analysis of the public employees' perceptions in South Korea. International Journal of Public Administration, 37(14), 1548. http://dx.doi.org/10.1080/01900690802243607

Kostova, T. (1999). Transnational transfer of strategic organizational practices: A contextual perspective. The Academy of Management Review, 24(2), 308-324. http://dx.doi.org/10.2307/259084

Ku, E. C. S., \& Fan, Y. W. (2009). Knowledge sharing and customer relationship management in the travel service alliances. Total Quality Management Business Excellence, 20(2), 1407-1421. http://dx.doi.org/10.1080/14783360903248880

Lai, H., \& Chu, T. H. (2002). Knowledge management: A review of theoretical frameworks and industrial cases. Proceedings of the 33rd Hawaii International Conference on System Sciences, IEEE. http://dx.doi.org/10.1109/HICSS.2000.926705

Liebeskind, J. P. (1996). Knowledge strategy and the theory of the firm. Strategic Management Journal, 17(3), 93-107. http://dx.doi.org/10.2307/2486993

Liedtka, J. (1999). Linking competitive advantage with communities of practice. Journal of Management Inquiry, 8(1), 5-16. http://dx.doi.org/10.1177/105649269981002

Liu, Y., \& Phillips, J. S. (2011). Examining the antecedents of knowledge sharing in facilitating team innovativeness from a multilevel perspective. International Journal of Information Management, 31(2), 44-52. http://dx.doi.org/10.1016/j.ijinfomgt.2010.05.002

Ma, Z., \& Qi, L. (2009). Toward an integrated customer knowledge management model: A process-based approach. Paper presented at the International conference on Management and Service Science (MASS 09), Wuhan, China. http://dx.doi.org/10.1109/ICMSS.2009.5305115

Makela, K., \& Brewster, C. (2009). Inter unit interaction contexts, interpersonal social capital, and the differing levels of knowledge sharing. Human Resource Management, 48(6), 591-613. http://dx.doi.org/10.1002/hrm.20300

McEvily, S., \& Chakravarthy, B. S. (2002). The persistence of knowledge-based advantage: An empirical test for product performance and technological knowledge. Strategic Management Journal, 23(4), 285-305. http://dx.doi.org/10.1002/smj.223

McLean, L. D. (2005). Organizational culture's influence on creativity and innovation: A review of the literature and implications for human resource development. Advance Development of Human Resources, 7(2), 226-246. http://dx.doi.org/10.1177/1523422305274528

Nejatian, H., Sentosa, I., Piaralal, S. K., \& Bohari, A. M. (2011). The influence of customer knowledge on CRM performance of Malaysian ICT companies: A Structural Equation Modeling approach. International Journal of Business and Management, 6(7), 181-198. Retrieved from http://www.ccsenet.org/journal/index.php/ijbm/article/view/8148

Okyere-Kwakye, E., \& Nor, K. M. (2011). Individual factors and knowledge sharing. Journal of Economic and Business Administration, 3(5), 66-72. Retrieved from http://thescipub.com/pdf/10.3844/ajebasp.2011.66.72

Othman, A. K. (2010). The influence of emotional intelligence on job performance in service businesses. $\mathrm{PhD}$ Thesis.

Pallant, J. (2001). SPSS survival manual: A step by step to data analysis using SPSS. Australia: Allen \& Unwin.

Park, C. H., \& Kim, Y. G. (2003). A framework of dynamic CRM linking marketing with information strategy. Business Process Management Journal, 9(5), 652-671. http://dx.doi.org/10.1108/14637150310496749

Platts, J., \& Yeung, M. (2000). Managing learning and tacit knowledge. Strategic Change, 99(6), 347-355. http://dx.doi.org/10.1002/1099-1697(200009/10)9:6<347::AID-JSC496>3.0.CO;2-M

Riege, A. (2005). Three-dozen knowledge-sharing barriers managers must consider. Journal of Knowledge Management, 9(3), 18-35. http://dx.doi.org/10.1108/13673270510602746

Rollins, M., \& Halinen, A. (n. d.). Customer knowledge management competence: Towards a theoretical framework. System Sciences, 2005. HICSS'05. Proceedings of the 38th Annual Hawaii International Conference. http://dx.doi.org/10.1109/HICSS.2005.180

Rowley, J. (2002). Reflections on customer knowledge management in e-business. Qualitative Market Research: 
An International Journal, 5(4), 268-280. http://dx.doi.org/10.1108/13522750210443227

Sharifuddin, S. O., \& Rowland, F. (2004). Benchmarking knowledge management in a public organization in Malaysia Benchmarking. An International Journal, 11(3), 238-266. http://dx.doi.org/10.1108/14635770410538745

Smith, H. A., \& McKeen, J. D. (2005). Developments in practice: Customer knowledge management: Adding value for our customers. Communications of the Association for Information Systems, 5(16), 744-755. Retrieved from http://ehis.ebscohost.com/ehost/pdfviewer/pdfviewer?vid=3\&sid=024cc861-30f0-4b95-910d-7da706aeb00 $8 \% 40$ sessionmgr112\&hid $=107$

Sorensen, H. E. (2009). Why competitors matter for market orientation. European Journal of Marketing, 43(5), 735-761. http://dx.doi.org/10.1108/03090560910947025

Spender, J. C., \& Grant, R. M. (1996). Knowledge and the firm: Overview. StrategicManagement Journal, 17(2), 5-9. Retrieved from http://www.jcspender.com/uploads/Spender Grant-SMJ_1996.pdf

Spinello, R. A. (2000). The knowledge chain. The Knowledge Management Yearbook 2000-2001, Butterworth-Heinemann, Woburn.

Tay, G., \& Shanks, E. (2001). The role of knowledge management in moving to a customer focused organization. In the 9th European Conference on Information Systems. Bled, Slovenia. http://dx.doi.org/10.1.1.107.9795

Tsiotsou, R. H. (2010). Delineating the effect of market orientation on services performance: A component wise approach. Service Industry Journal, 30(7), 375-403. http://dx.doi.org/10.1080/02642060802236103

Van den Hooff, B., \& De Ridder, J. A. (2004). Knowledge sharing in context: The influence of organizational commitment, communication climate and CMC Use on Knowledge Sharing. Journal of Knowledge Management, 8(6), 117-130. http://dx.doi.org/10.1108/13673270410567675

Von Krogh, G., \& Roos, J. (1996). A perspective on knowledge, competence and strategy. Personnel Review, 24(3), 56-76. http://dx.doi.org/10.1108/00483489510089650

Wang, Y., Liang, P., \& Chen, J. (2010). An empirical study on interaction among interpersonal trust, knowledge sharing and team performance. International Conference on Future Information Technology and Management Engineering. http://dx.doi.org/10.1109/FITME.2010.5654860

Yang, H. L. \& Wu, T. C. T. (2008). Knowledge sharing in an organization - Share or not? Technological Forecasting \& Social Change, 75(8), 1128-1156. http://dx.doi.org/10.1109/ICOCI.2006.5276482

Yang, J. (2007). The impact of knowledge sharing on organizational learning and effectiveness. Journal of Knowledge Management, 11(2), 83-90. http://dx.doi.org/10.1108/13673270710738933

Zhang, J., Liu, Y., \& Xiao, Y. (2008). Internet knowledge sharing system based on object-oriented. $2^{\text {nd }}$ International Symposium on Intelligence Information Technology Application. http://dx.doi.org/10.1109/IITA.2008.306

Zhou, K. Z., Brown, J. R., \& Dev, C. S. (2009). Market orientation, competitive advantage, and performance. A demand-based perspective. Journal of Business, 62(11), 1063-1070. http://dx.doi.org/10.1016/j.jbusres.2008.10.001

\section{Copyrights}

Copyright for this article is retained by the author(s), with first publication rights granted to the journal.

This is an open-access article distributed under the terms and conditions of the Creative Commons Attribution license (http://creativecommons.org/licenses/by/3.0/). 